\title{
Rethinking Deindustrialisation and male career crisis
}

\section{George Karl Ackers, University of Portsmouth U.K}

\begin{abstract}
The decline in manufacturing and growth of service based jobs has prompted many social theorists to argue that the ability of working class men to construct meaningful and rewarding careers is becoming ever more limited. Despite using the universal label 'working class' the experience of skilled working class men has been largely ignored. This article explores 26 work history interviews collected from 14 former Royal Dockyard tradesmen in South East England and 12 of these men's sons and grandsons. Findings from this research challenges the idea that most men were/and are passive victims of industrial change. By contrast, the majority of men in this study managed to carefully adapt to and navigate the transition from industrial to post-industrial work whilst still retaining a 'linear life narrative' (Sennett, 1998) to give meaning to their evolving careers and lives.
\end{abstract}

\section{Keywords}

Deindustrialisation, male identity, 'crisis’ of masculinity, career transition

\section{Introduction}

This article addresses the debates concerning the impact of deindustrialisation and move to a post-industrial 'new economy' on working class men. Set within the industrial context of the former naval repair community in South East England, my study suggests that the move from industrial to post-industrial work was not precarious for the men in this study 
on the whole. Indeed, the majority of these men managed to find relatively stable employment and gain internal promotion. Further, for a section of these men, 'career adaptability’ (Super and Knasel, 1981) and 'job crafting’ (Wrzesniewski and Dutton, 2001) led to promotion and a major increase in wages. This career transition resulted, however, in most of these former Dockyard trade workers and a proportion of their sons and grandsons moving away from skilled manual work and into new careers with very different skill sets.

Three intergenerational themes were central to the men's explanations of how they tackled transition in their working lives. The first theme, 'getting on' reflects evidence that the men’s career motivations and attitudes were primarily focused on upward career mobility and better job security. The second theme 'personal adaptability' was the strategy of adapting skills and embodying new work identities that the men used to actualize their motivation to 'get on'. However in the transition to post-industrial work the men did not lose their engagement with their trade learning and hands on work. The third theme 'craft' illustrates how the men developed unpaid DIY projects, to retain a 'linear life narrative' (Sennett, 1998), which gave meaning to their evolving careers and lives. Additionally these craft projects recreated channels through which fathers, sons, and grandsons talked about their growing and changing relationships with each other.

The career opportunities available to these men were in part a consequence of their geographical location, with a large number finding work in London. However, taking advantage of these opportunities was a product of their active agency, and can be put down to the initiative shown by these men in constructing their own careers. In this sense, they were not passive ‘victims’ of deindustrialisation.

\section{The literature on contemporary 'working class men as the victims of loss'}


The contemporary literature on deindustrialisation and the move to a post-industrial 'new economy' has overwhelmingly portrayed working class men as the victims of loss. Two related forms of loss are commonly cited in a literature which spans the topics of work, gender and community.

Due to deindustrialisation and globalisation a current theme in much grand social theory is that since the 1980s a new phase of 'flexible capitalism' has emerged. In this, collective forms of labour are being replaced with individualised and disjointed work. Beck (2000) argues that this is having a very acute effect on the working class, as the industrial 'job for life' is disappearing and being replaced by precarious and poorly paid work. On the topic of 'flexible capitalism', Sennett's (1998) work, The Corrosion of Character, is particularly relevant to this study as it uses a similar cross generational sample of fathers and sons. He explores the personal consequences of this transition through a comparison of Enrico, a Janitor, and his son Rico, a technology advisor. Sennett argues that Enrico's working life as a janitor had provided him a stable occupation and local community through which to understand his life as a 'linear narrative'. Rico had achieved upward career mobility in comparison to his father and become a technology advisor. However, due to the shorttermism endemic to 'flexible capitalism', he had persistently moved between disjointed jobs across America. Sennett argues that this disjointed career had rendered him without the secure identity leading him to question what meaningful message he could send to his children. Thus, according to these theories, it is not only the decline of manufacturing but also the nature of flexible capitalism that erodes the opportunity of working class men to construct meaningful and rewarding careers.

Alongside becoming the victims of structural transformation, working class men are commonly cited as the victims of gendered identities and masculine practices which they cannot fulfil. The majority of studies on former industrial communities cite a separation 
between a residual image of physical work and the jobs open to this generation of working class men. Jimenez and Walkerdine's (2010 p.185) study of a former steel town in Wales found men 'feel bullied and shamed by their families, peers and others in the community for not being able to find gender-appropriate work'. Thus, working class men are the victims of gendered socialisation and feel that new forms of service work are 'antithetical to the masculine working class habitus' (Nixon, 2009 p.300). A range of cross national studies argue that this inadequacy contributes to a crisis of masculinity, resulting in more male aggression and protest masculinities (See Bourgeois, 1995; Nayak, 2003; Connell 1996). Although the work of MacDowell (2003) has suggested that working class men are capable of constructing multifaceted masculine identities to reconcile service work and residual physical images of masculinity, her study, like those above, exclusively focuses on unskilled working class men.

\section{The Research project and Methods}

This article draws on the author's $\mathrm{PhD}$ research on the impact of deindustrialisation on masculine work identity for generations of men in South East England. It is over a quarter of a century since this Royal Dockyard closed its doors in 1984. The 'Dockyard' a, naval shipbuilding and repair yard, was the major employer for generations of men and their families over its four hundred year history. Prior to its closure, the Royal Dockyard was the principal employer in the town, directly employing 7,000 people with several thousand other jobs linked directly or indirectly to the maritime industry in the early 1980s. To follow the generational significance of the Royal Dockyard a mutigenerational sample was used to explore the long term and residual effect of deindustrialisation on male work identities in transition. Therefore, 26 work history interviews were conducted with two generational 
samples of men, in 2011-12. The first sample was based on 14 former Dockyard tradesmen. Half of these men's fathers had worked in the dockyard, with many referencing generational employment stretching back hundreds of years. For example, Peter Wood, a former Patternmaker and Woodwork teacher, had traced members of his family working in the Dockyard since 1710. All 14 of the men in the first sample were skilled tradesmen, having completed apprenticeships of 3 to 5 years at the Dockyard. Of this group, 12 were still working in the Dockyard in the early 1980s, during the period of decline and closure. The second sample was based on work history interviews with 12 of the former Dockyard workers' sons and grandsons. 7 of the 12 men in the second sample currently lived and worked outside the Dockyard town, with 5 now based in London.

The majority of interviews were recorded in the participant's family home. Interviews on average lasted 60-90 minutes and were all recorded and transcribed verbatim. A semi structured interviews guide was given to participants before being interviewed with a range of suggested topic for discussion. However, most participants constructed their interviews on a chronological account of their lives and careers. All names of the research participants were then anonymised and replaced by culturally appropriate pseudonyms. Data analysis followed Braun and Clarke's (2006) phases of thematic analysis. Interviews from these two samples of men were initially analysed separately, with the aim to make a comparison between work identities in the different generations. During the process of data analysis, however, it became apparent that cross generational themes were being continued and re-interpreted by these men. In short, the evidence suggested continuity rather than rupture. To illustrate these cross generational relationships and themes, this paper will focus on a sub-group of four families as presented in Table 1 below. In the following section, therefore, the three main cross generational themes of a 'getting on' philosophy to work, 'personal adaptability' and a 'craft outlook’ will be considered. 
Table 1. The Research samples - main occupation across generations of male kin

\begin{tabular}{|c|c|c|c|}
\hline Pre Generation * & $\begin{array}{l}1^{\text {st }} \text { Generation } \\
\text { The former } \\
\text { Dockyard workers }\end{array}$ & $\begin{array}{l}2^{\text {nd }} \text { Generation } \\
\text { Sons of former } \\
\text { Dockyard workers }\end{array}$ & $\begin{array}{l}3^{\text {rd }} \text { Generation } \\
\text { Grandson of } \\
\text { former Dockyard } \\
\text { workers }\end{array}$ \\
\hline $\begin{array}{l}\text { James Wood, } \\
\text { Engine fitter } \\
\text { ( } 7^{\text {th }} \text { generations of men } \\
\text { in the wood family } \\
\text { who had worked at the } \\
\text { Dockyard since the } 17^{\text {th }} \\
\text { century ) }\end{array}$ & $\begin{array}{l}\text { Peter Wood, } \\
\text { former Patternmaker } \\
\text { and Woodwork } \\
\text { teacher }\end{array}$ & $\begin{array}{l}\text { Philip Wood, } \\
\text { Shipping agent }\end{array}$ & $\begin{array}{l}\text { John Wood, } \\
\text { PhD student in } \\
\text { music technology }\end{array}$ \\
\hline \multirow[t]{2}{*}{$\begin{array}{l}\text { Bill Copper, } \\
\text { Unskilled labourer } \\
\text { (1 } 1^{\text {st }} \text { generations of the } \\
\text { Copper family to work } \\
\text { at the Dockyard) }\end{array}$} & \multirow[t]{2}{*}{$\begin{array}{l}\text { Francis Copper, } \\
\text { former Shipwright, } \\
\text { inspector of } \\
\text { Shipwrights and } \\
\text { Health and Safety } \\
\text { advisor }\end{array}$} & $\begin{array}{l}\text { Chris Copper, } \\
\text { former Marine } \\
\text { Engineer and } \\
\text { London Police } \\
\text { officer }\end{array}$ & \\
\hline & & $\begin{array}{l}\text { Harry Copper, } \\
\text { Electrical fitter }\end{array}$ & \\
\hline $\begin{array}{l}\text { Doug Wright, } \\
\text { Chef in the Army }\end{array}$ & $\begin{array}{l}\text { William Wright, } \\
\text { former Shipwright, } \\
\text { Draughtsmen and } \\
\text { HRM executive } \\
\text { manager }\end{array}$ & $\begin{array}{l}\text { Mark Wright, } \\
\text { former Army } \\
\text { Mechanical } \\
\text { Engineering and } \\
\text { current MD of his } \\
\text { own IT } \\
\text { subcontracting firm }\end{array}$ & \\
\hline $\begin{array}{l}\text { Frank Hermiston, } \\
\text { Bus conductor }\end{array}$ & $\begin{array}{l}\text { Ben Hermiston, } \\
\text { former shipwright } \\
\text { recorder and retired } \\
\text { Co-op Worker }\end{array}$ & $\begin{array}{l}\text { James Hermiston, } \\
\text { former BT engineer } \\
\text { and senior manager }\end{array}$ & \\
\hline
\end{tabular}

*The Pre Generation were not interviewed but referenced by the 1st Generation of former Dockyard workers in their interviews

\section{Theme one: A 'getting on' philosophy to work}

'Getting on' as a theme developed from the common and recurring rationalization that these men use to make career choices during their working lives. For both samples, different career decisions were made with a consistent focus on long term upward career mobility and better job security. Within this study 'getting on' theme seemed to first occur due to the 
influences of the men's parents. For this generation of former Dockyard tradesmen, the majority came from unskilled backgrounds, reflecting that their parents had advised them that doing a trade apprenticeship was a secure foundation on which to start their careers.

I remember saying to my father, 'Right I'm off in the navy'. 'Oh he said, 'I shouldn't do that, go in the Dockyard and do your apprenticeship and when you've got your indentures you can do what you like'. So I was persuaded and I don't begrudge him that. (Francis Copper, former Shipwright, inspector of Shipwrights and Health and Safety advisor)

My father was an engine fitter and turner so he often came home very mucky, and my mother wasn't keen on me getting my hands dirty. She wanted a clean-coloured son, but my father said 'It was a reliable government job, and if you became established you got a pension'. So I did the exam and became a Patternmaker, it was also a less mucky trade which pleased my mum. (Peter Wood, a former Patternmaker and Woodwork teacher)

As parents themselves these men stressed a similar 'getting on' philosophy to their sons. However, for this generation trade work was no longer emphasized. Instead as these men recalled their parents encouraged them to go into secure white collar work.

Dad used to advise me, to not leave school but to stay on and get some ' $O$ ' levels. He thought I should go into a bank and be a manager. (Chris Copper, a former Marine Engineer and London Police Officer) 
A friend of my father had a shipping company, and he said to my father, 'If you send him along I might have a vacancy coming up'. So I did go along, it was a small privately owned shipping office on the High Street, so I started as a tea boy really and worked my way up from there. (Philip Wood, a retired Shipping Agent)

First created in the men's relationship with their parents, a 'getting on' philosophy to work commonly recurred as the men described their developing careers. For the first sample, ten of the fourteen men achieved promotions into non manual positions whilst working in the Dockyard. The majority of these men saw the move away from work, 'at their tools', as a conscious career decision and necessary consequence of gaining promotion. Due to being promoted, these men had to develop new office based skills and become accustomed to white collar roles. This transition within the Dockyard was cited by many as the key to 'getting on' after deindustrialisation.

Having achieved promotion into the Health and Safety department, one of my main roles was to do talks in different departments of the yard, about risks and hazards. So in my career after the yard closed, I used that knowledge in my new job, going to different industries, like British Cables, to do Health and Safety talks to their workforce. (Francis Copper)

As far as I was concerned my apprenticeship and training was a key to many doors, if I wanted to go through them, so the door I chose was teaching. Everybody said to me, 'When you go for a job, get off the wood bench', but I didn't want to get off it, I enjoyed what I did. The workshop was a teaching environment, so I became a woodwork teacher. (Peter Wood) 
The motivation to 'get on' also continued in the career decisions of the sample of sons and grandsons; with the extrinsic desire for a secure wage used to construct their on-going careers.

My career developed by what you might call, 'natural progression'. You see I'm the sort of person that won't take any risks, so career-wise I stayed with one company until I retired. On the one hand I didn't get the big promotions, but on the other hand there aren't many with as good a pension as me. (Philip Wood)

So for job security for my family, I decided to retrain as a policeman. Some of my friends said, 'I don't know how you can deal with all those sights like bone's hanging out of people', but it's part of your job, and you get on. (Chris Copper)

A 'getting on' philosophy to work is by no means distinct to this studies generation of Dockyard tradesmen. Instead, this should be viewed as a historical continuation of aspirational attitudes consistent in both Dockyard communities and the occupational culture of skilled tradesmen. This is reflected in the research by Water (1999) on Dockyard workers in the 1970s, in which he argues that the desire for upward mobility was an essential part of Dockyard communities. Such a path afforded by the fixed term Dockyard apprenticeships which offered 'the able and industrious lads to rise from labouring levels to middle-class status, have a better life and feel the superiority of their own knowledge'(Water 1999 p.88). Further, Reid's (2004) book on British trade unions, United We Stand, suggests that such aspirations were a part of the occupational culture of most groups of skilled tradesmen dating back to $18^{\text {th }}$ century craft societies. As he characterizes 'the craftsmen were living in an urban 
environment in which there was a range of alternative types of employment, well-developed networks of information, and a culture of economic calculation’ (Reid, 2004 p.30).

\section{Theme two: 'Personal adaptability'}

Like three of the four men above, the careers of most men in both samples, developed and changed considerably during their working lives. This alone is not surprising since this sample was constructed to explore the effect of deindustrialisation. However, what became clear in these men's interviews was, first, that they did not see themselves as passive victims of economic change and, second, that as individuals they felt a large degree of control over change in their career. Thus 'personal adaptability' is defined as the on-going strategy of adapting skills and embodying new work identities with the aim to 'get on' at work. Using 'personal adaptability' as a means to 'get on' was most clearly and concisely reflected by William.

I've had a very rewarding and fulfilling career because I've been willing to do those different things... It's not good enough just to be good at what you're doing. You have to put yourself out there, got to go beyond what is familiar and comfortable, to enable you to progress and advance. (William Wright, a former shipwright and HRM executive manager)

In practical terms, many of the men's careers after the Dockyard closed seemed to have little in common with their formative trade work. However, 'personal adaptability' was a strategy the majority of men saw as embedded in their formative experiences of work as individually autonomous tradesmen in the Dockyard.

I think my practical background has helped me innumerable times. It gives you a much better insight into other areas, it helps you to visualize things 
and think about how you can alter them. People perhaps feel that in a digital age, that's not important but I really think it is. (William Wright)

As tradesman we could make our own decisions on how to do things, which is the thing I took with me personally outside [the Dockyard]. That's when I went into different types of work, some of which did not appertain to anything to do with shipbuilding, but I found having that, training and confidence enabled me to, to stay in employment until retirement. (Ben Hermiston, a former Shipwright and retired Co-op Worker)

In the men's accounts, adaptation and innovation were seen as a coherent part of their roles and identity as Dockyard tradesmen. In short, the men did not define their status as tradesmen by a fixed group of skills or static set of work tasks. On the contrary, to work as tradesmen the men had to develop a constantly evolving range of skills and knowledge. For the vast majority, learning new skills and working in different contexts became a more overt and conscious part of their careers, when they achieved promotion to roles beyond their manual trades.

Becoming a draughtsman, I thought I might end up doing drawings all the time, but actually, they gave me some interesting problems. One was to work out how Russian subs were getting from one location to another many hundreds of miles away without refuelling. (William Wright)

Becoming a recorder for the finance department, I remember thinking, how am I going to cope it's like learning another language, at first, but as I went along I got to know the different jobs and when people were taking the mick, as you know, I'd already been using maths so that side wasn't too difficult.(Ben Hermiston) 
Similar to Ben Hermiston's quote above, a number of men recalled how becoming accustomed to these new roles was difficult at first. However none felt this caused a long term rupture in their work identities. Instead they saw taking on these new roles as consistent with their flexible attitude to work and learning. Thus personal adaption was a common feature of most of these Dockyard working lives, which continued in their varying careers beyond.

I recognised that information technology was the future, but apart a few technical staff, very few people seemed interested in the early 90s. So although it was outside my skill-sets as a surveyor, I did a training course and got on a special project in London to introduce computerisation to business. That was a pivotal move in my career because I ended up writing a lot of the business cases for the implementation of introducing different program and technology. (William Wright)

The career transition from trade work to information technology was also a common path for the sample of sons and grandsons. Both William Wright and Ben Hermiston son's careers had started with a trade apprenticeship and moved into information technology.

You can exhaust your technical knowledge and get to a point where nothing seems to stretch you anymore, and I could see that modernisation was coming, the introduction of digital systems and exchanges. So I saw, an opportunity to do an ONC in business studies day-release and so applied and got on that. (James Hermiston, former BT engineer and senior manager)

I was looking for a new challenge, after the army... and I didn't want to get stuck in an unexciting desk job, you know a link in a chain. So using the 
army fund I retrained as a Microsoft certified systems engineer. It was tough, very tough,... but there were similarities, not similar in material but, but both were practical step by step training so my engineering background helped me to see it was a process and to not get annoyed all the time. (Mark Wright, a former mechanical engineering in the army and current MD of his own I.T subcontracting firm)

As a theme, 'personal adaptability' seems to amalgamate the two different career concepts ‘career adaptability’ (Super and Knasel 1981) and ‘job crafting’ (Wrzesniewski and Dutton 2001). Savickas (1997) defines career adaptability, 'as the readiness to cope with the predictable tasks of preparing for and participating in the work role and with the unpredictable adjustment prompted by the changes in work and working conditions' (p.254). This concept emphasises the importance of an individual's capacity to adapt to the changing nature of employment, a process the majority of men in this study encountered. However, it does not seem to account for individuals as active agents, changing their work and transforming the nature of employment within organisations. This process is most clearly illustrated in William, James and Mark’s accounts above: first, as they define adaption as self motivated and, second, as their own actions change the nature of their working conditions.

Thus the men in this study display the ability to change and redefine aspects of their work in a proactive manner. In Wrzesniewski and Dutton’s (2001) terms, these 'Individuals have latitude to define and enact the job, acting as "job crafters." We define job crafting as the physical and cognitive changes individuals make in the task or relational boundaries of their work' (2001, p. 179). However, within this research, the concept of 'job crafting' does not simply belong to one 'job' but instead forms part of an ongoing career strategy of 'personal adaptability'; a strategy the men enact across their working lives and in the different job contexts of their careers. Further, as the next theme craft demonstrates, this 
strategy also played a role in how the men redefined their trade work as craft and shifted this from a paid to an unpaid activity.

\section{Theme three: 'craft'}

A 'craft outlook' was a theme generated from the way a number of men within both samples talked about their relationship with the work they did. This theme became evident in the first sample's description of their relationship with Dockyard trade work. However a 'craft outlook' in this sense is different from an occupational trade, since it reflects the personal outcomes that individuals felt they gained from their work. Trade in a more simple sense just reflects the skills and demarcated work of a particular occupational group.

I enjoyed shaping wood, but it was more than that, there's a philosophical aspect to it. Humanity depends upon these [pointing to hand and head], It makes us human, so to speak if nothing else. As I started out saying, 'your head and hands are attached', and if you don't use both together, you're not human, It's a great tragedy that modern humanity doesn't use them together. (Peter Wood)

Interest, sometimes it made work a damn sight harder. You'd have people saying, 'hey come on it's about time you packed up', and you'd be thinking, 'No, let me just finish this bit', I just want to see this through. Because it's like a puzzle you'd be turning it over in your head all night not talking, used to drive my wife up the wall. (Francis Copper)

As reflected above, for most of these men paid work moved away from practising their Dockyard trades. But this transition did not end their engagement with trade learning and 
hands on work. Instead, most men talked about DIY as one of their main leisure interests. Although labelled DIY, this masked the quality, technicality and intrinsic value which these men associated with their craft (Mills, 1951; Sennett, 2008). These non-paid projects seemed to help these men to sustain a 'linear life narrative' (Sennett, 1998) and understand their lives and identity as a continued story and not a disjointed range of events.

Here you go see [pointing to a picture] it was a shell when we got it but we refitted that schooner, together over long time. Then we used to take it out for weekends. Well we got lost one weekend, we stopped in Belgium for a few days. (Peter Wood)

Francis Copper: Hours I spent, changing gearboxes for you and putting the clutches in.

Chris Copper: As a youngster, we built the garage and put the workshop on the side. So we were always in there, taking gearboxes, putting new clutches in, rebuilding me car engines.

Sarah Copper: Well your dad never did anything to your car, he always made you help him, not like next door, where the father used to do everything and the son used to stand there with their hands in his pocket.

Chris Copper: We've always been a hands-on, practical people. If I didn't know how to do it, I'd ask dad. Still do now, were off in a bit to finish my mother in laws kitchen. She moved to a bungalow, so we've been doing together for a while.

As reflected above, these home improvement projects were not only talked about by the former Dockyard workers, but also reflected on in the memories of these men's sons and 
grandsons. John Wood recalled spending a lot of time after school and during the school holidays at his grandparents' house, because his parents had to work irregular hours John's strongest memories were of spending time with his grandfather:

He's got a woodwork shed in his garden and I remember going there and building things out of wood, learning all about the different techniques. He would say, "Oh think about what it is you want to do", and then he'd make us plan it out before. I always really liked the tactile nature of working with materials and, I think I use quite a lot of those skills now, actually. (John Wood a PhD student in music technology and Grandson of Peter)

John returned to this theme later when talking about his own work and learning.

Music as sculpture, electro-acoustic music ... created with electronic and then using speakers you project it back into sound again, I really like this idea of building, pieces out of blocks of sound. I guess that comes from, working with my Granddad in his woodwork shed. (John Wood)

\section{Conclusion}

The themes generated from the skilled working class men in this study demonstrate an individual career strategy, which allowed them to navigate the transition from industrial to post-industrial work. In contrast to the dominant literature, these men did not see the move to non-industrial work as causing conflict with their working class images of masculinity. Unlike the families in Jimenez and Walkerdine (2010), manual work was not idealized. Instead, it was seen as one step on the path to 'getting on'. Further, within the men's description of their manual trade work, 'craft' instead of physicality was emphasised; finding 
satisfaction in their capacity as tradesmen to adapt skills and innovate within their roles. Therefore 'personal adaptability' alongside their motivation to 'get on', enabled these men to gain promotion into non manual roles both inside the Dockyard and in their careers in the new economy.

The importance of flexibility was common within the men's narrative. However, this did not seem to occupy the same dichotomy as is reflected in the literature on the emergence of 'flexible capitalism'. Instead, for the first sample, flexibility and individual motivation was embedded in their industrial work and individual working lives as tradesmen. These men viewed their work as non-static before deindustrialisation. So adapting to roles in the new economy seemed consistent with their flexible attitude to work and learning. For a section of both samples, changes, such as the development of communication technologies, were cited as pivotal to 'getting on' in their careers. As individuals they saw and acted on the opportunity to retrain and gain upward career mobility in these emerging sectors of the new economy.

Further, unlike Rico in Sennett (1998), none of these men felt that flexibility in their paid work disrupted their ability to construct a 'linear life narrative'. Instead, for the first sample, by practicing their trade skills in non-paid craft projects they managed to retain a sense of identity and a continued narrative from their time as apprentices through their changing working lives and into retirement. Memories and experiences of doing DIY were also a repeated channel through which father, sons and grandsons talked about their growing and changing relationships with one another. In a number of cases, these relationships were still being affirmed through working with each other on existing craft projects, or by men in non-trade work translating a craft outlook into their own careers. 
Whereas this study only speaks for a section of the skilled working class, these finding suggest that the current literature needs to be modified in three fundamental ways. First, the manual working classes should not be considered as a homogeneous or static group when responding to deindustrialisation. These skilled men experienced work transitions in a very distinctive way. Second, the experiences of the men in this study were further mediated by the regional employment context of the south east, whereas the current literature is largely based on isolated communities in the North of England or Celtic fringes. Third, unlike static studies of geographically located collective community experience, this research has followed generations of families. These individuals career stories reflects the important accounts of men who have strategically moved away or commute to work outside these former industrial areas. The omission of these three important factors, presents an over passive account of deindustrialisation and the move to the new economy, which robs many working class men of their individuality and active agency.

\section{Implications for career work with working class males}

To label working class men as ‘the passive victims of loss’ offers only barriers to this group's ability to construct meaningful careers in today's job market. Through this lens, this social group seems destine to fight over an ever declining pool of physical jobs in order to fulfil a notion of what male work should be. Although the men here did not fulfil this label or fall foul of these negative outcomes, caution should be taken not to propose generalised answers to questions about working class men and careers from the limited scope of this sample. Even so, given the depth of generational data, this approach could be a useful tool when giving career guidance to young working class men. 
Sennett's (1998) use of the term, linear life narrative, is closely associated with a single occupation within one organisation. By contrast, the men in this study managed to sustain their narrative through the different occupations jobs and craft projects across their working lives. For the majority, emphasis was placed on viewing their working life in context of, or in active dialogue with, the generation that went before. Thus these narratives were given a linear meaning by the men, who actively constructed their own links and themes to understand their working lives in coherence with their family backgrounds. This process embedded their careers in the values of their social class, however, removed their occupations became from stereotypical ideas of male working class jobs. Therefore, it was not the aim of these men to repeat the work of their father's, but instead to demonstrate to them that their working lives had been constructed along the same values.

Finally, the men’s accounts of their working lives echo Savickas' (2005) notion of 'careers stories', which he argue tell individuals 'how the self of yesterday became the self of today and will become the self of tomorrow' (p.58). In terms of career guidance for young working class men today, a useful tool could be to ask young men to write narrative accounts of their own families' working histories and to explore the values embedded in these accounts. This would allow them to make links between the working values they see as significant and the types of career opportunities open to them. As reflected in this study, John, James and Mark constructed links between physical trade learning and the process learning they did for their careers in information and music technology. A focus on values and socialization could thus help to remove any negative stereotypes associated with particular careers and also enable some young men to see their lives in continuity with their social and family backgrounds.

\section{References}


Beck, U. (2000). The Brave New World of Work. Cambridge: Polity.

Bourgeois, P. (1995). In Search of Respect: Selling Crack in El Barrio. Cambridge: Cambridge University Press.

Connell, R.W. (1996). Masculinities. Cambridge: Polity.

Faludi, S. (2000). Stiffed: the betrayal of modern man. London: Random House.

McDowell, L. (2003). Redundant Masculinities? Employment change and the white working class youth. Oxford: Blackwell.

Mills, C.W. (1951). White Collar: The American Middle Class. New York: Oxford University Press.

Nayak, A. (2003). 'Boyz to Men': masculinities, schooling and labour transitions in deindustrial times’, Educational Review, 2, 148-159. doi:10.1080/0013191032000072191

Nixon, D. (2009). 'I Can't Put a Smiley Face On’: Working-Class Masculinity, Emotional Labour and Service Work in the 'New Economy'. Gender, Work and Organization, 3, 300322. doi: 10.1111/j.1468-0432.2009.00446.x

Reid, A. (2004). United We Stand: A History of Britain's Trade Unions. London: Penguin Books.

Savickas, M. L. (1997). Career adaptability: An integrative construct for life-span, lifespace theory. The Career Development Quarterly, 45, 247-259. doi: 10.1002/j.21610045.1997.tb00469.x

Savickas, M. (2005). The theory and practice of career construction. In S.D. Brown \& R.W. Lent (Eds.), Career development and counselling: Putting theory and research to work (pp. 4270). Hoboken, NJ: John Wiley \& Sons. 
Sennett, R. (1998). The Corrosion of Character: The Personal Consequences of Work in the New Capitalism. London: Norton.

Sennett, R. (2008). The Craftsman. London: Penguin Books.

Super, D. E., \& Knasel, E. G. (1981). Career development in adulthood: Some theoretical problems and a possible solution. British Journal of Guidance \& Counselling, 9, 194-201. doi: 10.1080/03069888108258214

Waters, M. (1999). The Dockyardmen speak out. In K. Lunn \& A. Day (Eds.), History of Work \& Labour Relations in the Royal Dockyards (pp. 87-99). London: Mansell.

Wrzesniewski, A., \& Dutton, J. (2001). Crafting a job: Revisioning employees as active crafters of their work. Academy of Management Review, 26, 179-201.Retrieved from http://www.jstor.org/stable/259118 